\title{
Nonlinear Impact of the Marketing Mix on Brand Sales Performance
}

\author{
Rafael Barreiros Porto ${ }^{\dagger}$ \\ University of Brasília \\ Nolah Schutte da Rocha Lima ${ }^{\Omega}$ \\ University of Brasília
}

\begin{abstract}
The pattern of the impact that marketing activities exert on sales has not been widely examined in the literature. Many studies have adopted restricted linear perspectives, disregarding the empirical evidence. We investigated the nonlinear impact of the marketing mix on the volume of sales, volume of consumers and level of purchasing by each consumer, through a longitudinal study with panel data of brands and consumers simultaneously. We analyzed 121 brands during 13 months, with 793 purchases/month by consumers, through application of three generalized estimating equations. The results indicate that the marketing mix, especially branding and pricing, have a strong impact on all the dependent variables in nonlinear form, with good fits of the parameters. The joint effect generates economies of scale for the brands, while for each consumer the joint effect stimulates the gradual purchase of larger quantities. The study demonstrates eight impacting patterns of the marketing mix on the indicators investigated, with alterations in their order and weight for brands and consumers.
\end{abstract}

Keywords: Marketing mix. Sales. Panel data. Brand performance. Consumer volume.

Received in 20/02/2014; revised in 18/06/2014; accepted in 20/06/2014; divulgued in 01/09/2015

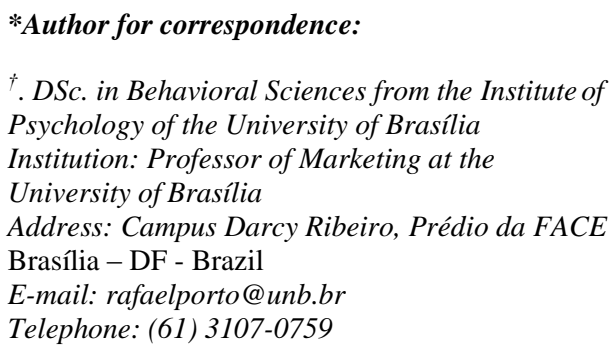

${ }^{\Omega}$ BSc. in Business Administration from the School of Economics, Administration and Accounting of the University of Brasília

Institution: Independent consultant in foreign trade and customer service team training

Address: Condomínio Ville de Montagne, Bairro Lago

Sul, Brasília - DF - Brazil

E-mail:nolahlima2@gmail.com

Telephone: ( 61) 3107-0759

Note from the Editor: The article was accepted by Emerson Mainardes. 


\section{INTRODUCTION} sales projections (FRANSES, 2006; NADAR; VIJAYAN, 2012) and is one of the most widely dependent variables used in marketing response models (BOWMAN; GATIGNON, 2010). When it is multiplied by the price, it is integrated to companies' performance measures (FARRIS et al., 2010), such as gross revenue, an indicator whose variation represent business growth (PENROSE, 1959). It is thus important to identify what causes this revenue component to increase or decrease.

The consumer volume metric of a brand - the numerator of the brand penetration metric (FARRIS et al., 2010) - is derived from the sales. The volume represents the customers responsible for buying a determined quantity of some branded product. Thenceforth, each customer acquires a volume of the product (specifically a package containing a branded product), which will be replaced only on the next shopping occasion. This volume per buyer (VAN HEERDE; NELSIN, 2008) reflects the volume sold, but on the demand side. It enables the customer to consume the item purchased immediately or to keep it for later consumption.

Ehrenberg (1995) was one of the pioneers to unite these metrics and demonstrate sales performance patterns of brands. His discoveries, which date back more than 50 years with replications for various products/services in various contexts and countries, form perhaps one of the leading empirical generalizations in the field of marketing (MITCHELL, 2011). Various studies have demonstrated market biases to favor large brands. The most extensively tested and used pattern, the "double jeopardy" pattern, occurs because small brands (those with small market share) suffer twice - they have fewer customers and these customers buy the brand less often in comparison with large brands. This pattern demonstrates that the metrics volume sold of the brand (numerator of market share), volume of consumers of the brand (numerator of market penetration) and average purchase of the brand by each consumer (numerator of behavioral loyalty) are interconnected (SHARP, 2011) and in some way benefit some brands and punish others. One of the conclusions of these researches is that a brand's market share growth comes mainly from an increase in its popularity, acquired by gaining more buyers (of all types), who are generally disloyal at the behavioral level, formed by light and heavy buyers.

However, despite having been extensively tested, the average buying frequency is an index that can distort the brand growth results. Since consumers often exhibit a multibrand 
pattern between shopping occasions (WELLS; FOXALL, 2013) and even within the same occasion (PORTO; OLIVEIRA-CASTRO; SECO-FERREIRA, 2011), it is not expected for consumers to be more loyal to a brand, but rather to buy a large volume of a brand on each occasion, more than other brands. Therefore, the consumer brand demand metric (FOXALL et al., 2011) - volume purchased per customer - can more faithfully capture a brand's growth than the measure of loyalty calculated by purchasing frequency.

However, the performance of brands is not a natural phenomenon and a consummated fact. It is generally constructed by means of marketing activities, which may or may not be effective in generating growth. Three central questions about brand performance regarding sales volume, customer volume and volume bought per customer: (1) What are the marketing mix components that generate the greatest impacts on these three indicators? (2) What format do these impacts have? and (3) Do they occur similarly for all routinely purchased brands?

This work aims to provide responses to these three questions. They involve the fact that retail marketing managers dedicate their efforts (formulate and schedule the marketing mix) to control the volume sold (generally, but not necessarily, with focus on increase FRANSES, 2006). Likewise, marketing managers of manufacturers (or brand managers) try to use marketing tools to make their brands more popular (KELLER; LEHMANN, 2006). In turn, consumers in generally want to extract utility or symbolic benefit from the products bought (FOXALL, 2005). Together, managers try to stimulate growth of the first two indicators, to extract profits or contribution margin per unit, while consumers try to acquire what suits them best, avoiding exorbitant payments as much as possible (WELLS; FOXALL, 2013).

This supply and demand conflict causes distinct impacts on the three metrics. Since a different marketing mix is used for each brand at different times, a dynamic relation exists. Hence, each of its components can generate immediate and/or extended increases or decreases. This extension is a path, which if traced out, may or may not reveal a pattern. If a large number of marketing activities are performed, including online tools, their impacts can be a combination of linear and nonlinear relations and this pattern can be uncovered. Unfortunately, these patterns have not yet been evidenced in the literature. Our aim is to clarify all these situations, by means of an empirical study with panel data of brands and consumers. 


\section{COMPOSITION OF SALES: VOLUME INDICATORS AS EVIDENCE OF BRAND GROWTH}

Some brands have higher sales, more buyers, and occasionally consumers buy more products of one brand than others (EHRENBERG; UNCLES; GOODHARDT, 2004; PORTO; OLIVEIRA-CASTRO; SECO-FERREIRA, 2011; SHARP, 2011), suggesting that the effects of the marketing mix (BOWMAN; GATIGNON, 2010) are not similar among brands. This has not been widely examined in the literature (KELLER; LEHMANN, 2006; HANSSENS; DEKIMPE, 2012) for not demonstrating the effects of economies of scale and the degree to which marketing strategies need to be implemented to generate changes in the pattern of quantity bought per consumer.

Van Heerde and Neslin (2008) revealed that marketing activities generate many phenomenon for brands sold at retail stores, such as: increase of sales of the category and outside the category, performance of brands, within-brand cannibalization, brand switching, store switching and acceleration or deceleration of buying. According to Ataman, Van Heerde and Mela (2010), the total (short-term plus long-term) sales elasticity is larger, respectively, for product, distribution, advertising and discounting. They also found that the long-term effects of discounting are one-third lower than the short-term effects and that the long-term effects of other spending on marketing mix are four times higher than the short-term effects. Besides this, Ramanathan and Muyldermans (2011) found that brand promotional activities are more influential on sales than seasonal aspects and holidays. Therefore, as a whole, there is strong evidence of widespread influence of the marketing mix on the growth of brands.

According to Franses (2006), although many studies have been published about sales volume, there are still unresolved gaps. In particular, these involve dynamic relations with ecommerce, the effect of the set of marketing actions for each brand instead of just their costs, models that consider consumer learning in reaction to these actions, and the overall impact of marketing actions.

A question that is at the heart of these gaps indicated by Franses (2006) is characterization of the structure of increased sales - whether due to an increase in number of buyers or volume purchased per buyer. Thus, the volume sold can be decomposed into the volume of consumers who buy a brand and the volumes purchased by them (SHARP, 2011). Ehrenberg, Uncles and Goodhardt (2004) and Mitchell (2011) demonstrated that when a brand's sales increase, this growth is due more to greater brand penetration than to buying frequency (behavioral loyalty), but both occur. Corkindale (2011) added that marketing 
efforts are more effective in expanding the brand's customer base than boosting customers' purchasing frequency and that increased loyalty is an illusory focus for growth of a brand. The impact of marketing actions on the frequency of buying has been well documented in the literature (JUNG; GRUCA; REGO, 2010), but the effects on the volume of consumers has rarely been considered, although this aspect has been suggested (EHRENBERG; UNCLES; GOODHARDT, 2004).

In turn, to decompose the volume bought per consumer (consumer demand), it is necessary to adopt individual delineations regarding consumers. Generally the models consider incidence, brand choice and quantity bought per customer (VAN HEERDE; NELSIN, 2008), each of which can accelerate or decelerate sales, altering stocks. Foxall (2010) describes some brand purchasing patterns for each consumer. The results on the quantity purchased indicate that each consumer tends to buy more on each shopping occasion when the price is lower (intra-consumer elasticity) and that groups of consumers that buy large quantities on average tend to pay lower prices (inter-consumer elasticity).

After each purchase of a given brand, consumers tend to pause for extended periods until the next purchase (OLIVEIRA-CASTRO; JAMES; FOXALL, 2007), suggesting stockpiling and planned buying, and that these behaviors are at least partially related to the marketing activities of each brand. Porto, Oliveira-Castro and Seco-Ferreira (2011) report evidence that the quantity of branded products bought by consumers can be decomposed into planning considering levels of utilitarian and informational benefits (combination of branding - dimensions of the consumer-based brand equity and dimensions of differentials). Subsets of brands that offer similar values and differentials compete with each other and consumers generally plan to buy them. But when consumers arrive at the store and have brand marketing strategies for that day, marketing activities cause them to buy different amounts than planned. If the amount actually bought is greater than planned, consumers tend to complement their purchases of brands with many differentials and high equity with those having few differentials and low equity, so that they adopt a mixed brand repertoire.

Our intention is to resolve some of these gaps in previous studies. There is little evidence whether a pattern of the impact that marketing activities exert on the sales volume and on its decomposition into volume of consumers and volume bought per consumer. Identifying this pattern can facilitate predictions of the effects of the marketing mix on these three indicators. Likewise, previous studies have not simultaneously evidenced the influence of promotional marketing (prices, retailers' advertising, etc.), non-promotional marketing 
(consumer based brand equity and differentials - together called branding) and online marketing (use of e-commerce, email marketing and electronic newsletters). This study covers all these variables composing the marketing mix and tests their impacts on each sales volume indicator for each brand.

\section{METHOD}

To assess the impact of marketing activities, we used longitudinal records and applied econometric modeling. The units of analysis were|: (1) total monthly sales of each brand, denoting the dependent variable, sales volume; (2) total monthly number of consumers who purchased each brand, as the dependent variable consumer volume; and (3) total monthly quantity of branded products purchased by each consumer, representing the dependent variable volume bought per consumer. Figure 1 illustrates the theoretical model tested. With it our aim was to test how these dependent variables are affected by the marketing activities (independent variables), composed of branding, pricing, availability and marketing communication. We also sought to fine a nonlinear prediction pattern between the independent and dependent variables.

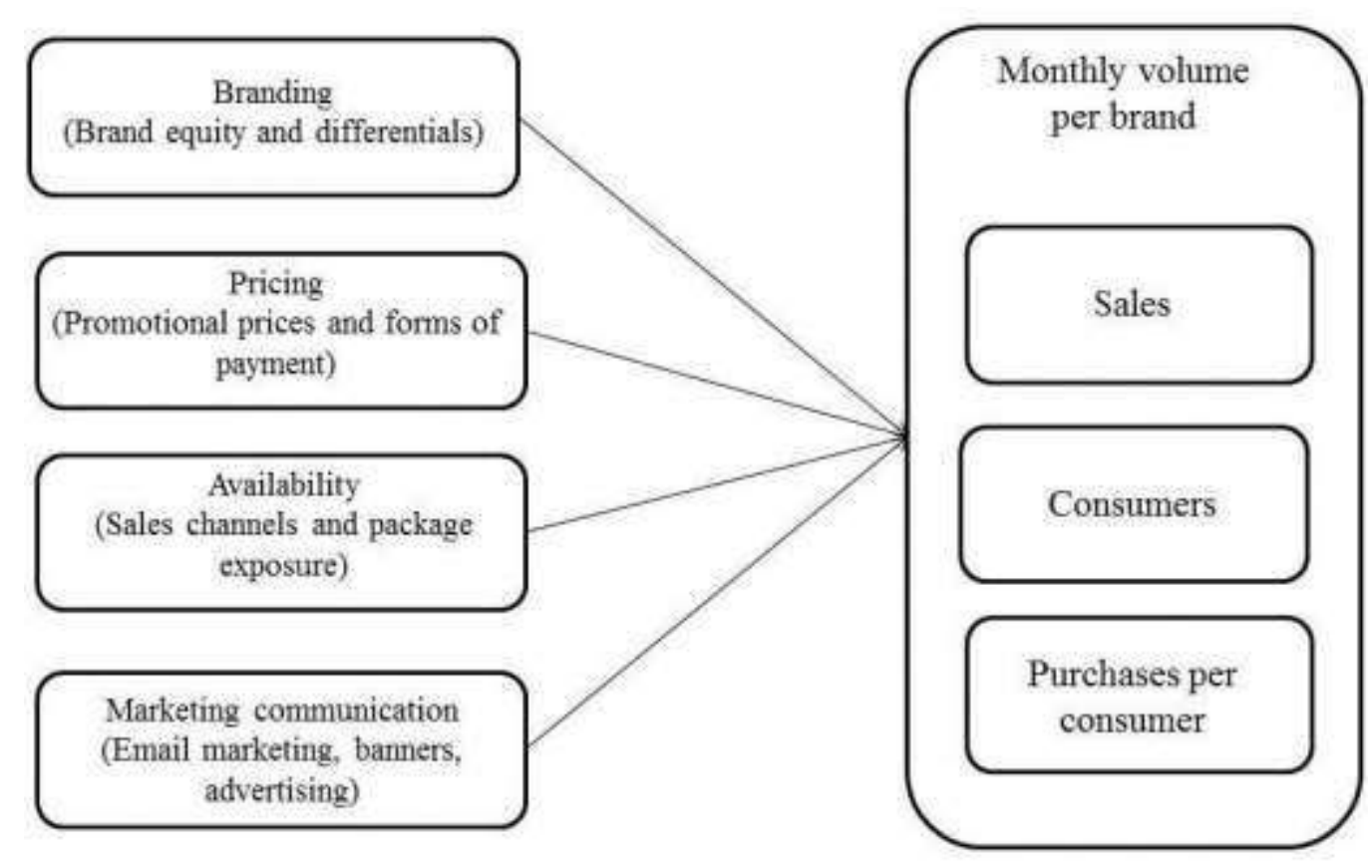

Figure 1 - Theoretical Model

We used a simultaneous panel of brands and consumers to enable collection of the data. Panel data studies, with focus on evaluation of programs, allow making temporal cause-effect inferences (COZBY, 2006), making them natural quasi-experiments (STOCK; WATSON, 2004), in which the absence (or low magnitude) of an independent variable and its presence (or high magnitude) at a later date make them similar to experiments, but naturally 
manipulated. Here these manipulations were exercised by the managers (retail store and manufacturers).

\subsection{DATA COLLECTION}

We gathered the data from a single drugstore that has been in business about one year. It has a multi-channel marketing strategy, selling both at the physical store and over the internet (e-commerce). The presence of the online channel affected the components of the marketing mix. Both the pricing and advertising strategies are differentiated by sales channel used by consumers. During the study period there were price differentiation promotions and various online advertising actions via institutional and commercial newsletters and banner ads. Besides drugs (over-the-counter and prescription, in the second case both branded and generic), the store carries the other typical health products: personal hygiene and grooming products, vitamins and food supplements, cosmetics, perfumes, first aid products, among others. All the store stocks approximately 4,500 items belonging to 200 brands. Of these, we analyzed 10 products and 121 brands.

We collected both primary and secondary data. We collected secondary data since the store's first month of operation for all 10 products, composing a sample of 13 months, between the start of May 2010 and end of May 2011. We analyzed approximately 793 brand purchases per month. This sample size presented a confidence interval of $95 \%$ and monthly error margin of 3.48. The sample power based on the multiple regression test, with medium size effect $\left(f^{2}=0.15\right)$ and all the predictors was on the order of $99.9 \%$, sufficiently good to minimize the risk of Type 2 errors.

We studied 10 products, mainly in the personal hygiene and grooming segment: toothpaste, body moisturizer, sunscreen, shampoo, hair dye, disposable diapers, diet aids, condoms, nail polish and sanitary napkins. We chose these products due to the availability of information: daily sales per product, per brand and sub-brand (package and bar code), unit price, unit weight, product attributes (differentials), sales channel, period for payment, newsletter date, date of advertising the product in newsletter, date of online availability and advertising in product banners posted at the site.

The company has two databases, both of which we used to collect the secondary data. The first, called the "Big System", consolidates the total sales (for management of sales, stock, suppliers and customers) and generates daily sales reports for each product, brand and sub-brand. The second system is based on the Google AdWords platform and generates reports on the online performance (sales and advertising actions carried out). From this last 
system we obtained a report on the newsletters sent, their dates and the brands/products offered. The banners of each brand were displayed for two weeks after advertising in the newsletter.

To determine the differentials of each brand, we used the method defined by Foxall, Oliveira-Castro and Schrezenmaier (2004), in which brands are classified by their attributes. We selected these differentials by the variety of attributes of the sub-brands, the information at the store's website and the packages of each brand. Thus, the brands with more attributes or different attributes than other brands were classified as differentiated brands and the others as not having differentials.

To obtain the primary data to identify the consumer-based brand equity, as validated by Oliveira-Castro et al. (2008), we applied structured questionnaires to measure the familiarity (Likert scale - 0 to 3 - for brand recognition) and quality perception (Likert scale - 0 to 3 for perceived quality) of each of the 121 brands analyzed. We generated a familiarity and perceived quality indicator (FQI) to measure consumers' recognition and perceived quality of each brand. We calculated harmonic means of these two metrics and aggregated them for each brand, without considering responses of people stating they did not purchase products with some regularity. The final sample was composed of 488 consumers (95\% confidence interval with error margin of $4.44 \%$ ). The primary data were collected by means of an online questionnaire.

\subsection{VARIABLES AND ANALYTIC PROCEDURE}

The means and standard deviations of each dependent variable were: monthly sales per brand $(\mathrm{M}=1.00 ; \mathrm{SD}=0.58)$; monthly volume of consumers per brand $(\mathrm{M}=1.00 ; \mathrm{SD}=$ $0.47)$; and sales volume per consumer $(\mathrm{M}=1.00 ; \mathrm{SD}=1.16)$. The means are equal to 1 because we relativized the dependent variables by their mean in all 13 months. This allows making comparisons between brands with different products, even when they have units with different measures, for being standardized. Each volume of a determined brand was multiplied by its weight (in grams, ml or units).

Figure 2 shows the brands' performance. The ratio between volume of consumers (numerator of the brand penetration index) with the volume purchased by the consumer (consumer brand demand) is an exponential curve. Besides this, the brands with higher sales volume (numerator of the market share index) generally have more consumers and these buy greater volume. This graph is similar to those that demonstrate the Double Jeopardy of brands in Dirichlet models (HABEL; LOCKSHIN, 2013), with the difference of being measured in 
volume (instead of percentage or frequency), so that it measured the average volume sold of each product investigated during the study period. As can be seen, the sample contains brands that exceed the mean consumer volume seven-fold, while others surpassed the average sales per consumer by a factor of 21 and others that exceeded the mean brand sales by 14 times.

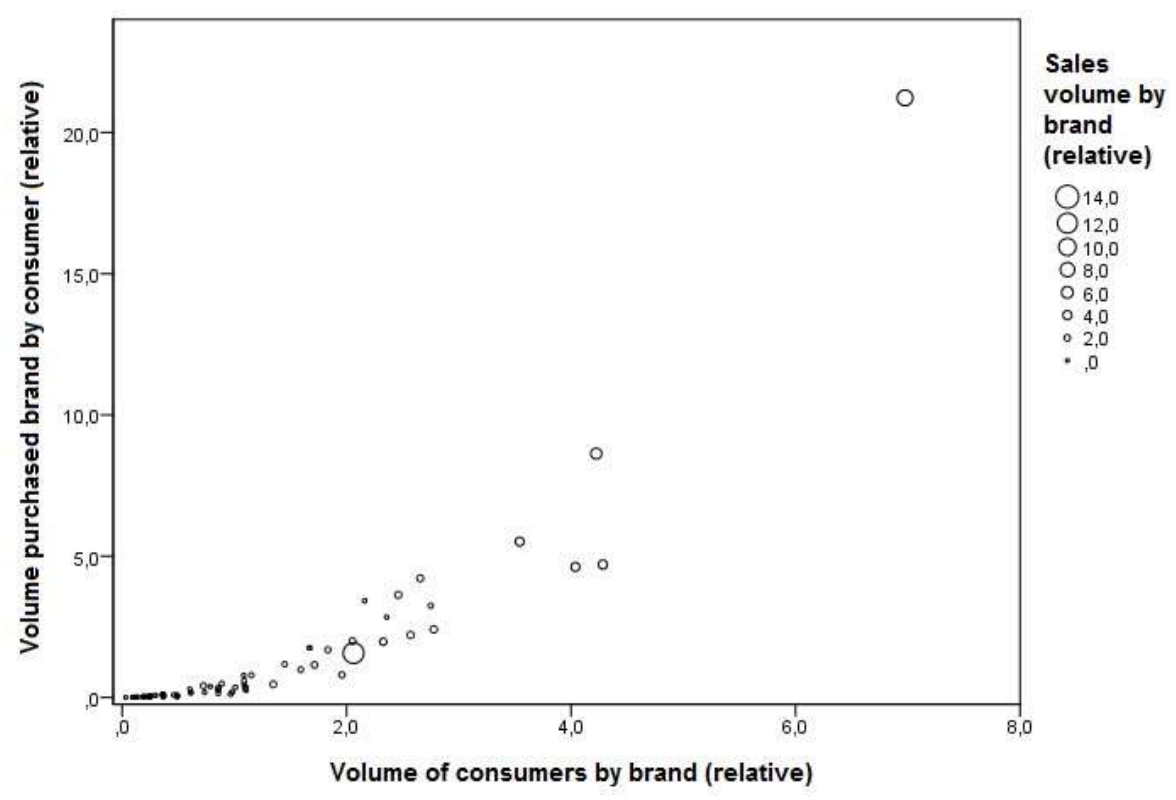

Figure 2 - Graph of Sales Performance of the Brands Investigated

Table 1 shows the descriptive analysis of the independent variables along with their formulas. It can be seen that some variables have high dispersion. In other words, their means are not a good representation of the typical value to analyze. Furthermore, variables on customers (which only enter the equation to predict the volume of each brand bought per consumer) have means near one, with low standard deviation. All of them have lower means and standard deviations than the corresponding values of the other independent variables, which enter to predict the sales volume and volume of consumers.

Because the longitudinal data are in monthly panels (by brands and/or consumers), we used Generalized Estimating Equations (GEE) for each dependent variable. We also used an unstructured correlation matrix, with robust estimator, because each observation (time) within the group (brand and/or consumer) had a different autocorrelation value. Since the dependent variables were not normally distributed and were not linearly related, we used the log-gamma link function for the variables sales volume and consumer volume per brand, since this function fit the data best. For the volume of brands bought per consume, we used the power link function (with a power of 3), again because it best fit the data. 
Table 1 - Descriptive Analysis of the Data and Description of the Formulas

\begin{tabular}{|c|c|c|c|}
\hline Name of the independent variable & Description of the formula & $\begin{array}{c}\text { Mean or } \\
\text { percentage }\end{array}$ & $\begin{array}{l}\text { Standard } \\
\text { deviation }\end{array}$ \\
\hline $\begin{array}{l}\text { Number of transactions per brand } \\
\text { by e-commerce }{ }^{a, b}\end{array}$ & $\begin{array}{l}\text { Sum of the number of monthly transactions } \\
\text { by e-commerce per brand }\end{array}$ & 1.70 & 1.26 \\
\hline $\begin{array}{l}\text { Exposure of package per brand at } \\
\text { the website }\end{array}$ & $\begin{array}{l}\text { Sum of the number of monthly package } \\
\text { exposures at site per brand }\end{array}$ & 4.40 & 5.90 \\
\hline $\begin{array}{l}\text { Advertising per brand in the } \\
\text { electronic newsletter }{ }^{\mathrm{a}, \mathrm{b}}\end{array}$ & $\begin{array}{l}\text { Sum of monthly advertisings in newsletter } \\
\text { per brand }\end{array}$ & 1.58 & 1.03 \\
\hline $\begin{array}{l}\text { Competing advertising in the } \\
\text { newsletter per brand }{ }^{a, b}\end{array}$ & $\begin{array}{l}\text { Sum of the monthly number of ads for } \\
\text { another brand of the same product disclosed } \\
\text { in the newsletter per brand }\end{array}$ & 1.17 & 0.49 \\
\hline $\begin{array}{l}\text { Advertising in electronic banner } \\
\text { at website per brand }{ }^{\mathrm{a}, \mathrm{b}}\end{array}$ & $\begin{array}{l}\text { Sum of the monthly number of advertisings } \\
\text { in the electronic banner per brand }\end{array}$ & 2.29 & 1.84 \\
\hline $\begin{array}{l}\text { Promotional price paid per brand } \\
\text { sold }^{\mathrm{a}, \mathrm{b}}\end{array}$ & $\begin{array}{l}\text { Unit price of the brand in month } \mathrm{X} \text { divided } \\
\text { by the average price of the brand in all } \\
\text { periods }\end{array}$ & 1.00 & 0.69 \\
\hline $\begin{array}{l}\text { Number of cash purchases per } \\
\text { brand }^{\text {a,b }}\end{array}$ & Sum of the monthly purchases paid in cash & 4.43 & 6.40 \\
\hline $\begin{array}{l}\text { Number of installment purchases } \\
\text { per brand }{ }^{\text {a,b }}\end{array}$ & $\begin{array}{l}\text { Sum of the monthly purchases made with } \\
\text { installments per brand }\end{array}$ & 1.56 & 1.19 \\
\hline $\begin{array}{l}\text { Number of transactions per } \\
\text { customer via e-commerce }{ }^{c}\end{array}$ & $\begin{array}{l}\text { Sum of the monthly number of transactions } \\
\text { by e-commerce per customer }\end{array}$ & 1.23 & 0.50 \\
\hline $\begin{array}{l}\text { Exposure of package at site per } \\
\text { customer }\end{array}$ & $\begin{array}{l}\text { Sum of monthly package exposures at site } \\
\text { per customer }\end{array}$ & 1.18 & 0.45 \\
\hline $\begin{array}{l}\text { Advertising in electronic } \\
\text { newsletter per customer }\end{array}$ & $\begin{array}{l}\text { Sum of the monthly advertisings in } \\
\text { newsletter per customer }\end{array}$ & 1.13 & 0.45 \\
\hline $\begin{array}{l}\text { Competing advertising in } \\
\text { newsletter per customer }{ }^{c}\end{array}$ & $\begin{array}{l}\text { Sum of monthly number of ads for other } \\
\text { brands of the same product disclosed in } \\
\text { newsletter per customer }\end{array}$ & 1.00 & 0.01 \\
\hline $\begin{array}{l}\text { Advertising in electronic banner } \\
\text { at site per customer }\end{array}$ & $\begin{array}{l}\text { Sum of monthly advertisings by electronic } \\
\text { banner per customer }\end{array}$ & 1.13 & 0.35 \\
\hline $\begin{array}{l}\text { Promotional price paid per } \\
\text { customer }^{\mathrm{c}}\end{array}$ & $\begin{array}{l}\text { Unit price of product purchased by customer } \\
\text { in month } \mathrm{X} \text { divided by average price of the } \\
\text { brand purchased in all periods }\end{array}$ & 1.00 & 0.08 \\
\hline $\begin{array}{l}\text { Number of cash purchases per } \\
\text { brand per customer }\end{array}$ & $\begin{array}{l}\text { Sum of the monthly brand purchases paid in } \\
\text { a cash per customer }\end{array}$ & 1.21 & 0.64 \\
\hline $\begin{array}{l}\text { Number of installment purchases } \\
\text { per brand per customer }\end{array}$ & $\begin{array}{l}\text { Sum of the monthly brand purchases paid in } \\
\text { installments per customer }\end{array}$ & 1.20 & 0.54 \\
\hline $\begin{array}{l}\text { Brand equity of the brand sold } \\
\text { (most equitable) }^{\mathrm{a}, \mathrm{b}, \mathrm{c}}\end{array}$ & $\begin{array}{l}\text { Code } 1 \text { if brand is above the average of the } \\
\text { FQI of other brands and code } 0 \text { otherwise }\end{array}$ & \multicolumn{2}{|c|}{$36.00 \%$} \\
\hline $\begin{array}{l}\text { Brand differentiation (greatest } \\
\text { differentiation) }\end{array}$ & $\begin{array}{l}\text { Code } 1 \text { if band has differentials based on } \\
\text { attributes and code } 0 \text { otherwise }\end{array}$ & \multicolumn{2}{|c|}{$44.60 \%$} \\
\hline $\begin{array}{l}\text { a: independent variable that ente } \\
\text { independent variable that entere } \\
\text { independent variable that entere }\end{array}$ & $\begin{array}{l}\text { the equation to predict the monthly sales vol } \\
\text { e equation to predict the monthly consumer } \\
\text { e equation to predict the volume purchased } p\end{array}$ & consumer & \\
\hline
\end{tabular}

\section{RESULTS}

We initially show the results referring to the impact of the marketing mix on the brand sales volume and then its impact on the volume of consumers of each brand and finally on the volume purchased per consumer. In each of these cases we demonstrate the estimates (B) with standard error and the graphs depicting the trend curves of the impact. 


\subsection{PATTERN OF THE IMPACT OF THE MARKETING MIX ON THE SALES VOLUME OF BRANDS}

The analysis of the impact of the marketing mix on the monthly sales volume presented good fits $(\mathrm{QIC}=150.23$; QICc $=210.4)$. The generalized explained variance had exponential behavior equal to $76.9 \%$, with good predictive power of the dependent variable over time in months (see Figure 3, Graph A). Since longitudinal panel analysis of the brands was used, each graph has its own curvature, with different fits (exponential $\mathrm{R}^{2}$ varied from $59.1 \%$ to 99.9\%), and all were well fitted in exponential form. Some examples for brands of the 10 products sampled can be seen in Figure 3 (Graphs B to D).
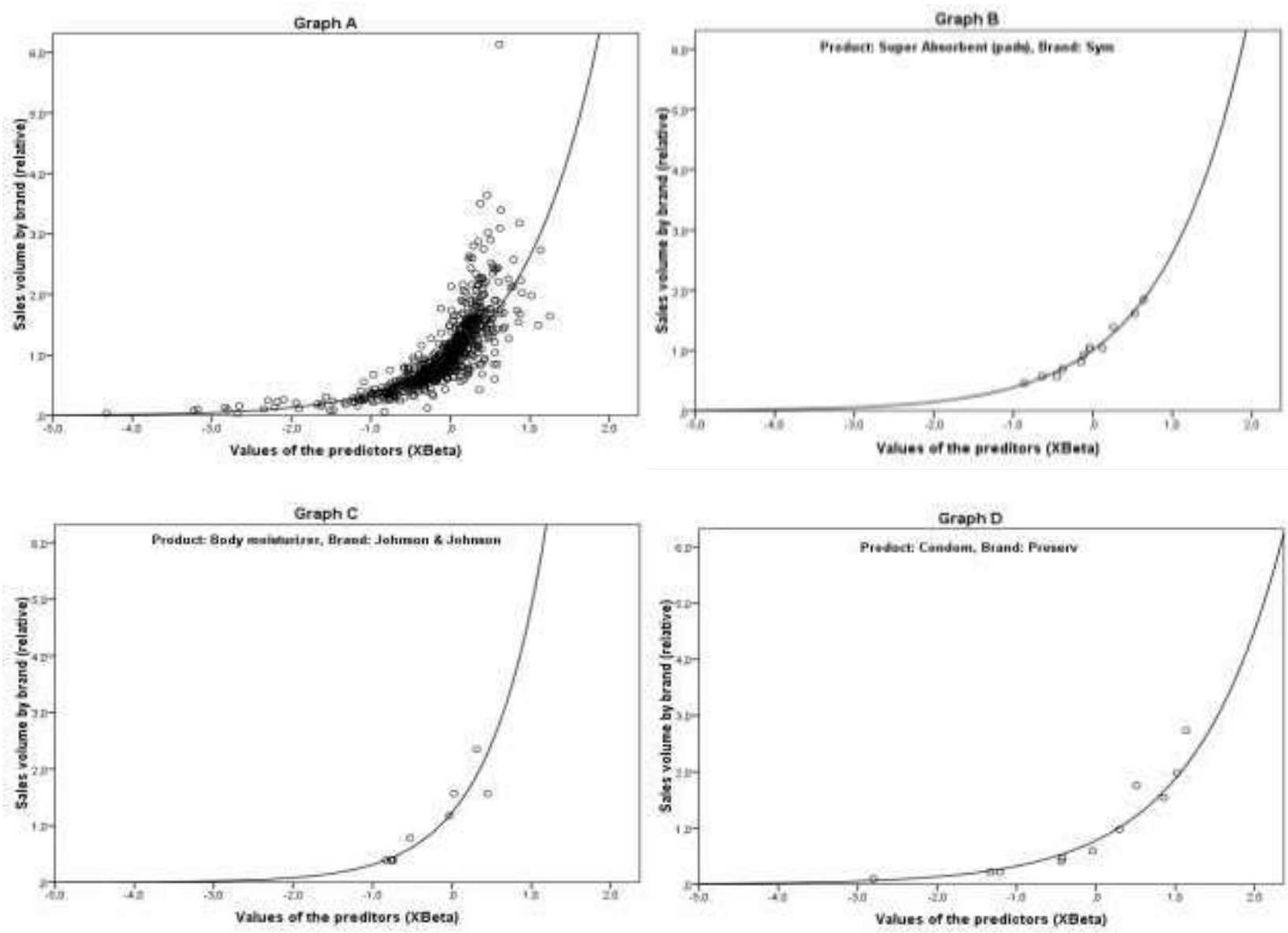

Figure 3 - Graphs of the Impact of the Marketing Mix on the Sales Volume of Each Brand

As a general result regarding the monthly sales volume (Table 2), the most important predictors were, respectively, brand differentiation $(B=0.68 ; p \leq 0.01)$, promotional price ( $B$ $=-0.63 ; \mathrm{p} \leq 0.01)$, level of consumer-based brand equity $(\mathrm{B}=0.48 ; \mathrm{p} \leq 0.01)$, number of ecommerce transactions $(B=0.13 ; p \leq 0.01)$, number of payments in cash per brand $(B=0.03$; $p \leq 0.01)$ and exposure of package at the online retail site $(B=0.02 ; p \leq 0.01)$. The other variables did not have a significant effect. In general, the greater the values (or lower in the case of promotional price) of these independent variables were, the greater the monthly sales 
volumes of the brands were, with exponential growth. In other words, these marketing activities, when carried out too strongly and/or with high magnitude, have a disproportional effect on sales volume, favoring brand proliferation. The compound variable branding (brand differentiation and brand equity) and price discounts were highly influential on the sales volume. The convenience of online sales (availability) and varied forms of payment (transaction facility) had also had a positive effect, to a lesser degree.

Table 2 - Strength of the Relation Between Marketing Mix and Sales Volume

\begin{tabular}{|c|c|c|}
\hline \multicolumn{3}{|l|}{ Dependent variable: Monthly sales volume of the brand } \\
\hline Independent Variables & $\mathbf{B}$ & $\begin{array}{c}\text { Standard } \\
\text { error }\end{array}$ \\
\hline Intercept** & 0.90 & 0.13 \\
\hline Number of online transactions per brand by e-commerce $* *$ & 0.13 & 0.02 \\
\hline Exposure of product packages at website $* *$ & 0.02 & 0.01 \\
\hline Advertising in electronic newsletter & 0.01 & 0.02 \\
\hline Competing advertising in newsletter & -0.01 & 0.08 \\
\hline Advertising of banners at website & 0.00 & 0.03 \\
\hline Promotional price for brand $* *$ & -0.63 & 0.06 \\
\hline Number of payments in cash per brand $* *$ & 0.03 & 0.01 \\
\hline Number of installment purchases per brand & 0.03 & 0.02 \\
\hline Consumer-based brand equity** & 0.48 & 0.08 \\
\hline Level of brand differentiation** & 0.68 & 0.06 \\
\hline Exponential $\mathrm{R}^{2}$ & & 76.9 \\
\hline QICc (reference value: 585,8 ) & & 210.4 \\
\hline
\end{tabular}

The greater sales mean more demand and purchases of the particular brand. However, this can occur due to a larger number of consumers and/or more purchases on average by each consumer. The next analyses demonstrate these effects.

\subsection{PATTERN OF IMPACT OF THE MARKETING MIX ON THE VOLUME OF CONSUMERS OF EACH BRAND}

The analysis of the impact of the marketing mix on the monthly volume of consumers of each brand presented reasonably good adjustments $(\mathrm{QIC}=129.00$; $\mathrm{QICc}=340.43)$. The general explained variance had exponential performance equal to $73.5 \%$, with good predictive power on the dependent variable during the months (see Figure 4, Graph E). Since longitudinal panel analysis of the brands was used, each graph has its own curvature, with different fits (exponential $\mathrm{R}^{2}$ varied from $42.0 \%$ to $99.4 \%$ ), and all brands were well fitted in exponential form. Some examples for the 10 products with different brands can be seen in Figure 4 (Graphs $\mathrm{F}$ to $\mathrm{H}$ ). 

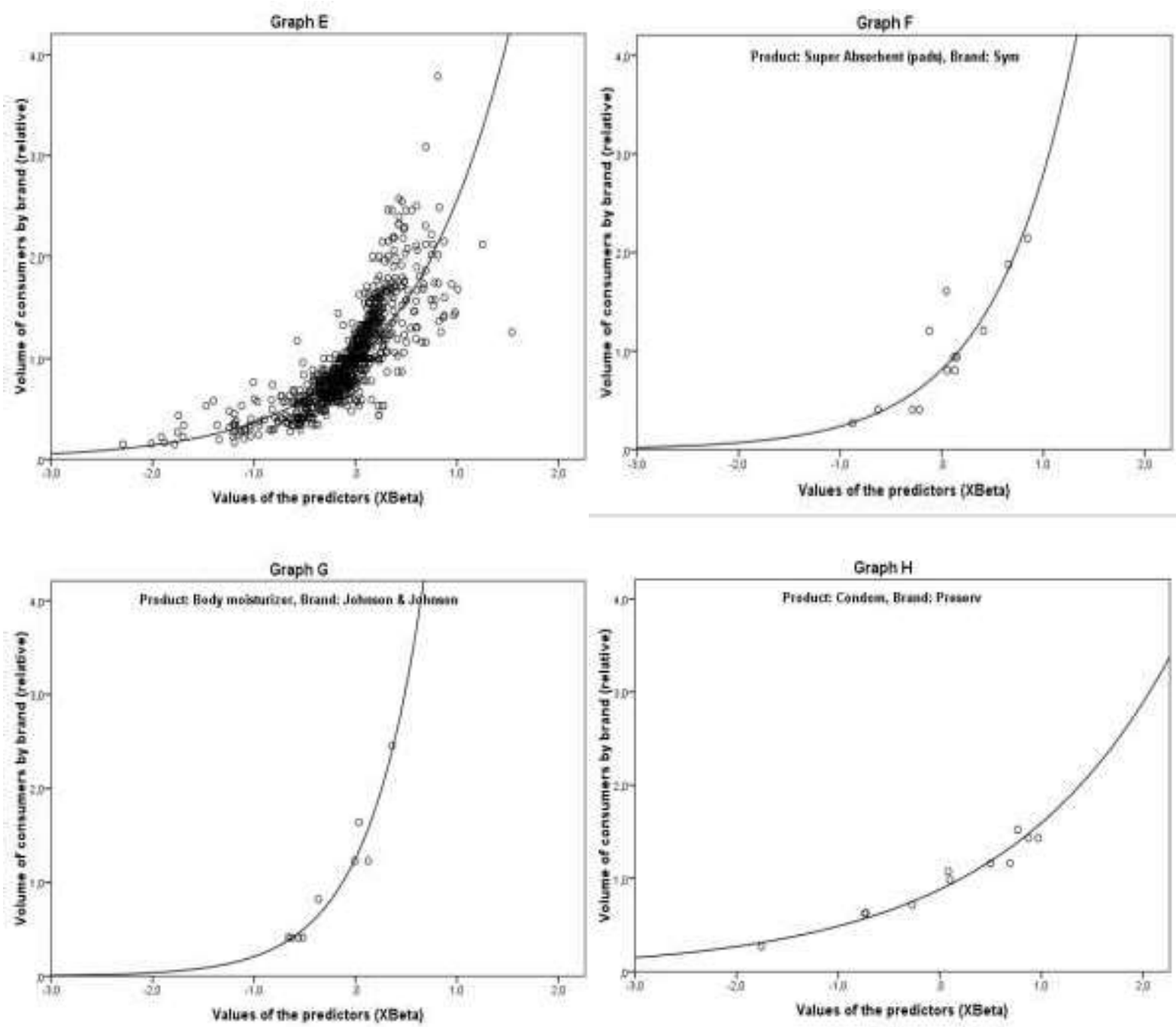

Figure 4 - Graphs of the Impact of the Marketing Mix on the Volume of Consumers of Products of Each Brand

All told, the results indicate that the strategies were very effective in increasing the number of consumers for some brands, but less effective for others, suggesting no impact or other sources that attract consumers (e.g., store advertising of the brand, marketing actions of other complementary products), not investigated in this study.

As a general result on the monthly volume of consumers (Table 3), the most important predictions were, respectively, the consumer-based brand equity $(\mathrm{B}=0.61 ; \mathrm{p} \leq 0.01)$, promotional prices offered for the brand $(\mathrm{B}=-0.31 ; \mathrm{p} \leq 0.01)$, level of brand differentiation $(B=0.30 ; p \leq 0.01)$, number of payments in cash of the brand $(B=0.09 ; p \leq 0.01)$, number of installment purchases of the brand $(\mathrm{B}=0.08 ; \mathrm{p} \leq 0.01)$, advertising in the electronic newsletter - email marketing $(\mathrm{B}=0.06 ; \mathrm{p} \leq 0.01)$, advertising in banners at the retailer's website $(B=0.03 ; \mathrm{p} \leq 0.01)$ and exposure of product packages at the retailer's website $(\mathrm{B}=$ $0.02 ; \mathrm{p} \leq 0.01)$. The other variables did not have a significant effect. In general, the greater the 
values (or lower in the case of promotional price) of these independent variables were, the greater the monthly volume of consumers of the brands were, with exponential growth.

Table 3 - Strength of the Relation Between Marketing Mix and Volume of Consumers

\begin{tabular}{l|c|c}
\hline Dependent variable: Monthly volume of consumers of the brand & $\begin{array}{c}\text { Standard } \\
\text { error }\end{array}$ \\
\hline Independent Variables & 0.34 & 0.15 \\
\hline Intercept** $^{*}$ & 0.05 & 0.03 \\
\hline Number of online transactions per brand by e-commerce & 0.02 & 0.00 \\
\hline Exposure of product packages at website** & 0.06 & 0.02 \\
\hline Advertising in electronic newsletter** & 0.03 & 0.05 \\
\hline Competing advertising in newsletter & 0.03 & 0.01 \\
\hline Advertising of banners at website** & - & 0.05 \\
\hline Promotional price for brand** & 0.31 & 0.01 \\
\hline Number of payments in cash per brand** & 0.09 & 0.01 \\
\hline Number of installment purchases per brand** & 0.08 & 0.01 \\
\hline Consumer-based brand equity** & 0.61 & 0.11 \\
\hline Level of brand differentiation** & 0.30 & 0.08 \\
\hline Exponential $\mathrm{R}^{2}$ & 73.5 \\
\hline QICc (reference value: 449,55) & 340.43 \\
\hline$*$ p $\leq 0.05 ; *$ p $\leq 0.01$ &
\end{tabular}

Among other factors, we call attention to the fact that communication efforts, although having a weak effect, prompted an increase in the number of consumers, in contrast to the monthly sales volume. Hence, these marketing activities, when carried out too strongly and/or with high magnitude, have a disproportional effect on sales volume, favoring growth of some brands and not of others. Besides increasing the number of consumers, the actions of the marketing mix can have an additional effect: causing individual consumers to buy greater quantities. The next analysis covers this aspect.

\subsection{PATTERN OF THE IMPACT OF THE MARKETING MIX ON THE VOLUME OF BRANDS PURCHASED PER CONSUMER}

The analysis of the impact of the marketing mix on the monthly volume purchased per consumer had good fits $(\mathrm{QIC}=27.5$; QICc $=188.8)$. The general explained variance had exponential performance equal to $75.1 \%$, with good predictive power on the dependent variable during the months (see Figure 5, Graph I). Again, since longitudinal panel analysis of the brands was used, each graph has its own curvature, with different fits (Power $\mathrm{R}^{2}$ varied from $64.1 \%$ to $99.1 \%$ ). Some examples can be seen in Figure 5 (Graphs J to L). The power format of cube root best fit the data for most of the brands, but not all had the same form due to sample limitation. Some consumers purchased the same brand only a few times in 
quantities different than the average (low dispersion). Hence, their behavior was described by a horizontal line to the XBeta axis.

Graph I shows the general relation, Graphs $\mathrm{J}$ and $\mathrm{K}$ depict the relation for a single consumer, with different products and brands, and Graph L shows the pattern of the volume purchased by another consumer who consumed the same brand as the consumer in Graph J. It can be seen that the alternation of one brand to another by the same consumer does not greatly change the curve's slope. However, when the consumer changes, even when maintaining the brand, the curve's slope behavior becomes very different, now with a power function. Therefore, some consumers can be more sensitive to marketing strategies and purchase a larger volume than other consumers under the same brand marketing conditions.
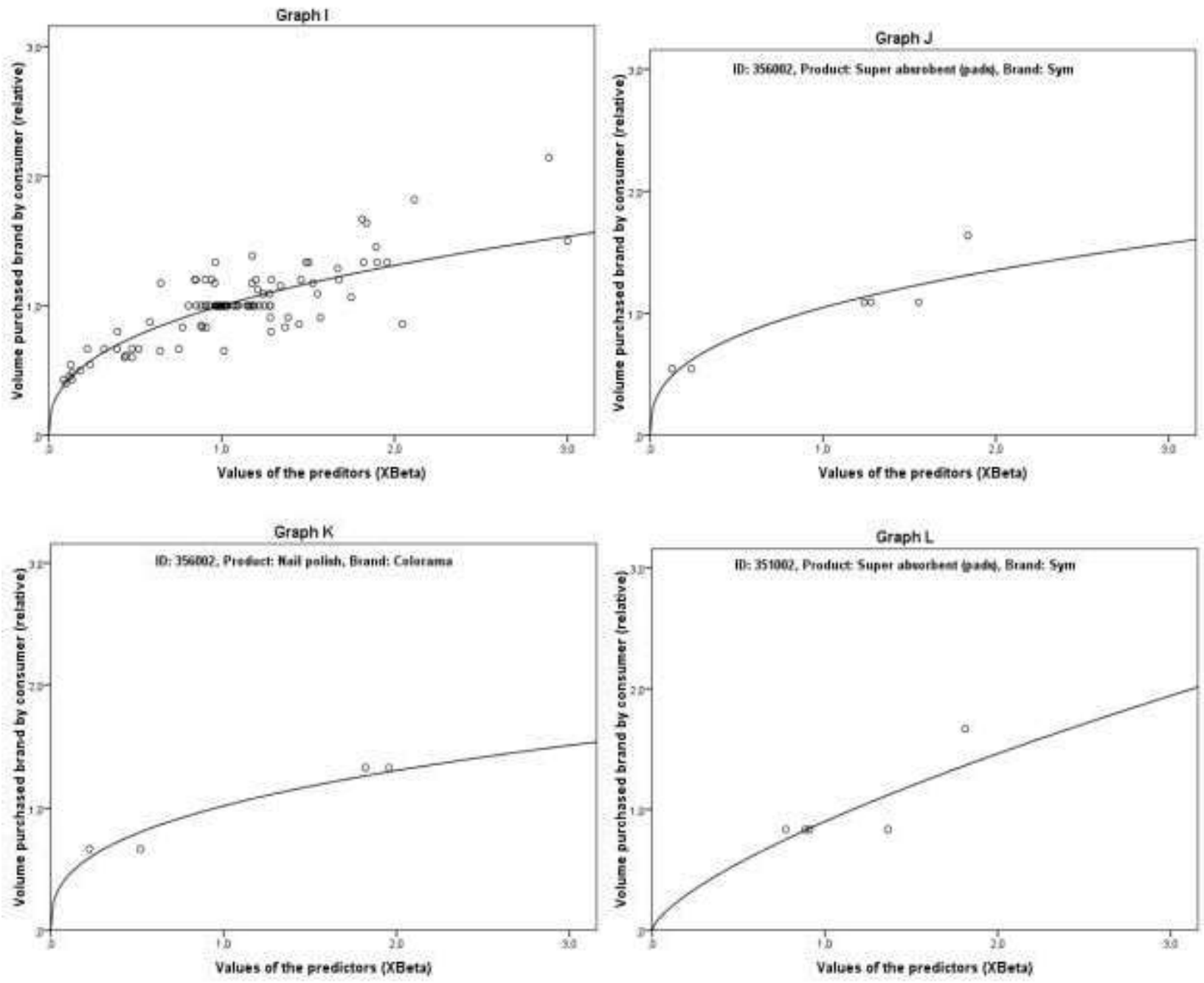

Figure 5 - Graphs of Impact of the Marketing Mix on the Volume Purchased of Each Brand per Consumer

As a general result on the monthly volume bought per consumer (Table 4), the most important factors were, respectively, promotional prices offered for the brand $(\mathrm{B}=-1.43 ; \mathrm{p} \leq$ $0.01)$, consumer based brand equity level $(B=0.32 ; \mathrm{p} \leq 0.05)$, number of payments in cash ( $\mathrm{B}$ 
$=0.24 ; \mathrm{p} \leq 0.05)$, number of installment purchases $(\mathrm{B}=0.23 ; \mathrm{p} \leq 0.05)$, number of online transactions by e-commerce $(\mathrm{B}=0.05 ; \mathrm{p} \leq 0.05)$ and brand differentiation level $(\mathrm{B}=0.04 ; \mathrm{p} \leq$ 0.05). The other variables did not have a significant impact. In general, the greater the values (or lower in the case of promotional price) of these independent variables were, the greater the monthly volume bought per consumer was, with cube root growth.

Table 4 - Strength of the Relation Between Marketing Mix and Volume Purchased per Consumer

\begin{tabular}{l|c|c}
\hline Dependent variable: Monthly volume of the brand purchased per consumer & $\begin{array}{c}\text { Standard } \\
\text { error }\end{array}$ \\
\hline Independent Variables & 0.64 & 0.15 \\
\hline Intercept** $^{*}$ & 0.05 & 0.03 \\
\hline Number of online transactions by e-commerce* & -0.05 & 0.07 \\
\hline Exposure of product packages at website per customer & -0.05 & 0.03 \\
\hline Advertising in electronic newsletter per customer & 0.03 & 0.04 \\
\hline Competing advertising in newsletter per customer & 0.06 & 0.06 \\
\hline Advertising of banners at website per customer & -1.43 & 0.07 \\
\hline Promotional price paid by customer** & 0.24 & 0.13 \\
\hline Number of payments in cash per customer* & 0.23 & 0.11 \\
\hline Number of installment purchases per customer * & 0.32 & 0.14 \\
\hline Consumer based brand equity $*$ & 0.04 & 0.02 \\
\hline Level of brand differentiation $*$ & 75.1 \\
\hline Power R ${ }^{2}$ & 188.8 \\
\hline QICc (reference value $=256.4)$ &
\end{tabular}

\section{DISCUSSION}

In general, the results demonstrate similar and nonlinear patterns of impact of the marketing mix on the volume sold, whether decomposed into volume of consumers and/or volume purchased per consumer. This clarifies some of the relations found between metrics in the marketing performance area (FARRIS et al., 2010). Other authors, although assuming that marketing actions affect brand metrics (KELLER; LEHMANN, 2006; BOWMAN; GATIGNON, 2010; HANSSENS; DEKIMPE, 2012), or finding partial relations of one or another action (VAN HEERDE; NESLIN, 2008; ATAMAN; VAN HEERDE; MELA, 2010), have not shown the format of this influence when using several actions simultaneously.

In specific terms, the results indicate that among promotional actions (VAN HEERDE; NESLIN, 2008), price-cutting promotional campaigns have the greatest influence on all the metrics studied, suggesting that for sales volume, promotional pricing is the main predictor. But the branding variable (KELLER; LEHMANN, 2006; OLIVEIRA-CASTRO et al., 2008; FOXALL, 2010), depending on the performance metric, can be more relevant than promotional actions, including price promotions. Furthermore, the communication variables 
were only relevant for the volume of consumers, corroborating the findings on buying patterns of Ehrenberg, Uncles and Goodhardt (2004). Therefore, in-store marketing communication strategies help brand penetration in greater magnitude (SHARP, 2011).

The study of brand performance (KELLER; LEHMANN, 2006; MITCHELL, 2011) is enriched by including consumer behavioral aspects (FOXALL, 2010) by providing complementary findings and explanations of the latter to the former. Even though consumers only rarely deviate from their average quantity purchased, when they do, this reveals an impact of marketing activities described by a cube root equation. In counterpart, these same activities generate exponential impacts on sales and number of consumers per brand. Hence, the joint effect of the marketing mix generates scale economies for brands, compensating their use starting from a particular level of impact. Before this threshold, the effect is virtually nil. For consumers, the effect of the same activities stimulates them to buy greater quantities, for stockpiling or immediate consumption, but only in gradual doses. Therefore, the effects are complementary, but not similar, on the consumer and brand levels.

This study expands the area of sales forecasting (FRANSES, 2006; NADAR; VIJAYAN, 2012) by indicating patterns of joint impact of the marketing mix on indicators of volume of sales, volume of consumers and volume purchased per consumer. Some of the patters on the volume of a brand sold are: (1) marketing mix activities can have a strong exponential influence on the performance of particular brands, but not on all; and (2) the variables branding, pricing and availability convenience (online) are the main predictors. In turn, the decomposition of the sales volume into volume of consumers demonstrated the following effects: (3) marketing activities can also exert a strong exponential influence on certain brands, but not on all, (4) the branding and pricing variables are their main predictors, and (5) online marketing communication variables have a positive impact in attracting buyers, but with less importance than the previous variables.

This panel data study of consumer behavior reveals other complementary patterns of the decomposition of sales volume, not clarified in the literature (FRANSES, 2006; JUNG; GRUCA; REGO, 2010; CORKINDALE, 2011). In specific terms, the results for the volume purchased per consumer show the following patterns: (6) the marketing mix activities have a strong power influence (cube root) for each brand, (7) the variables price promotion, consumer-based brand equity and payment facility are the main predictors, and (8) the marketing mix only has slight effect with small alterations, i.e., large alterations are necessary to increase (or reduce) the volume purchased. Therefore, large variations prompt a change in 
the buying level, which will tend to remain steady with subsequent small alterations. This last finding complements the results reported by Porto, Oliveira-Castro and Seco-Ferreira (2011), revealing that when consumers adopt a mixed repertoire for buying quantity, the marketing mix induces increased purchasing quantity, especially of brands that have stimulation strategies, even small brands (EHRENBERG; UNCLES; GOODHARDT, 2004).

Comparison of the results of the sales volume, consumer volume and volume bought per consumer indicators shows that the prediction variables are similar, with analogous effects, although generally changing in their order and weight of impact for each brand and/or consumer. In other words, each brand and each consumer has a specific impact equation. Therefore, if a manager wants to predict how much of a brand $\mathrm{X}$ product will be sold (one of managers' interests - FRANSES, 2006), if changing the marketing activities analyzed in this study, the following equation will apply: $\mathrm{Y}_{\mathrm{it}}=\mathrm{a}_{\mathrm{it}} * \exp \left(\mathrm{X} *\right.$ beta $\left.\mathrm{a}_{\mathrm{it}}\right)$. For example, the equation for L'Oreal sunscreen is given by $\mathrm{Y}_{\mathrm{it}}=1.05 * \exp (1.22 * \mathrm{X})$. A value of $\mathrm{X}$ equal to 0.504 (equivalent to having two e-commerce transactions, four monthly exposures of the package at the website, sending one newsletter with the brand per month, having monthly competing advertising in the newsletter, two monthly banners at the website, presence of differentials, being perceived as an equitable brand, one monthly payment in cash, three monthly installment purchases and a price 0.53 higher than the average price) causes a predicted value for sales $\left(Y_{i t}\right)$ of 1.94, representing an increase of 0.94 in its average sale value (value $\left.Y_{i t}=1\right)$.

A similar equation predicts the volume of consumers (relative). This equation can be a useful tool for managers to predict the brand penetration indicator (SHARP, 2011). The equation for L'Oreal sunscreen is given by $\mathrm{Y}_{\mathrm{it}}=1.15 * \exp (1.51 * \mathrm{X})$. An $\mathrm{X}$ value equal to 0.351 (with the same configuration as in the preceding example) causes a value of 1.95 for the volume of consumers, representing an increase of 0.95 in the average value for number of consumers.

To increase the volume purchased per consumer of the same brand of this product, meaning affecting the consumer performance (FOXALL et al., 2007; FOXALL, 2010; WELLS; FOXALL, 2013), each consumer has a specific equation. For example, the consumer with code 952002 would have a power equation for the L'Oreal sunscreen brand given by: $\mathrm{Y}_{\mathrm{itc}}=0.93 * \mathrm{X}^{(0.74)}$. Therefore, an $\mathrm{X}$ value of 1.339 (two e-commerce purchases per month, two exposures per month to the package at the website, no newsletter received, and as a consequence, no exposure to competing advertising by the retailer, two monthly exposures to a banner at the website, purchase of this brand which has differential and additional value, 
two installment purchases during the month and a price paid of 0.7 above the average price) causes a predicted increase of 1.15 in the volume of the brand purchased by this consumer, giving an increase of 0.15 of the average value exclusively by this consumer for this brand.

\section{CONCLUSIONS AND IMPLICATIONS FOR MANAGERS}

The study demonstrates there are eight patterns of the impact of the marketing mix on the sales volume indicator and on two other indicators that decompose the first one. Marketing professionals wanting to stimulate increased sales of a brand can partly manipulate their marketing mix. By doing this, the marketing activities cause effects that can be described by curves with positive slopes for each indicator. Therefore, when implementing a particular marketing strategy, the decision-maker can decide between stimulating the number of consumers of a brand and/or stimulating the volume bought per consumer. To achieve the second effect it is necessary to make sharp changes in the strategies to change the buying level, which in turn requires a minimum limit to benefit from the scale gains of exponential growth.

Therefore, the marketing mix has effects on sales growth of brands. But these effects occur more strongly for some brands (and/or for some consumers) and less for others. Not all activities work for all brands, and the same applies to the effects on consumers. Therefore, managers should target those activities to brands that generally do not receive much marketing effort, because this can generate exponential effects on sales and the number of consumers, if the objective is to increase these indicators. If the objective is to increase the amount purchased by a typical consumer, there should be a large alteration of the marketing activities to generate this effect.

Even though the results show the existence of different patterns of influence, we only analyzed 121 brands and 10 products that are routinely purchased, for a period of 13 months. There are many other brands and products that are less frequently purchased. Future studies can investigate whether the patterns of the relations demonstrated here are similar for other products. Also, future studies can investigate other marketing strategies (store marketing strategies or manufacturer advertising, etc.) and individual variables that can influence buying behavior.

Finally, this study provided answers to some gaps, both theoretical and empirical, about the pattern of influence of the marketing mix on the results of efforts to promote sales. This pattern is not linear and branding activities are equally (or more) important in relation to pricing (promotional price cuts), payment facilities and implementation of new online sales 
channels. Furthermore, isolated brand communication actions, even online ones, have more timid effects, but even so they are more effective to increase the number of consumers of a brand. Since many of the models in the literature assume linear effects, the impact of the marketing mix on sales volume and/or number of buyers has been underestimated, and the effect on volume purchased per consumer has been overestimated.

\section{REFERENCES}

ATAMAN, M. B.; VAN HEERDE, H. J.; MELA, C. F. The long-term effect of marketing strategy on brand sales. Journal of Marketing Research, v. 47, n. 5, p. 866-882, 2010.

BOWMAN, D.; GATIGNON, H. Market mix and marketing response models: trends and research opportunities. Foundations and Trends in Marketing, v. 4, n. 3, p. 129-207, 2010.

CORKINDALE, D. Discovering how brands grow. The Marketing Review, v. 11, n. 4, p. 337-345, 2011.

COZBY, P C. Métodos de pesquisa em ciência do comportamento. São Paulo: Atlas, 2006.

EHRENBERG, A. S. C. Empirical generalizations, theory, and method. Marketing Science, v. 14, n. 3, Supplement, p. 20-28, 1995.

EHRENBERG, A. S. C.; UNCLES, M. D.; GOODHARDT, G. J. Understanding brand performance measures: using dirichlet benchmarks. Journal of Business Research, v. 57, n. 12, p. 1307-1325, 2004.

FARRIS, P. W. et al. Marketing metrics: the definitive guide to measuring marketing performance. Upper Saddle River, New Jersey: Wharton School Publishing, 2010.

FOXALL, G. R. Understanding consumer choice. New York: Palgrave Macmillian, 2005. Invitation to consumer behavior analysis. Journal of Organizational Behavior Management, v. 30, n. 2, p. 92-109, 2010.

FOXALL, G. R. et al. The behavioral economics of brand choice. Basingstoke, UK: Palgrave Macmillan, 2007.

FOXALL, G. R. et al. The behavioral economics of consumer brand choice: patterns of reinforcement and utility maximization. Behavioural Processes, v. 66, n.3, p. 235-260, 2004.

FOXALL, G. R. et al. Brand-related and situational influences on demand elasticity. Journal of Business Research, v. 66, n. 1, p. 73-81, 2011.

FRANSES, P. H. Forecasting in marketing. In: ELLIOT, G.; GRANGER, C.; TIMMERMANN, A. (Eds.). Handbook of economic forecasting. Oxford: North Holland, 2006. p. 983-1012.

HABEL, C.; LOCKSHIN, L. Realizing the value of extensive replication: a theoretically robust portrayal of double jeopardy. Journal of Business Research, v. 66, n. 9, p. 1448-1456, 2013. 
HANSSENS, D. M.; DEKIMPE, M. G. Short-term and long-term effects of marketing strategy. In: SHANKAR, V. et al. (Eds.). Handbook of marketing strategy. Northampton, USA: Edward Elgar Publishing, 2012, p. 457-469.

JUNG, S.; GRUCA, T.; REGO, L. Excess loyalty in CPG markets: a comprehensive examination. Journal of Empirical Generalizations in Marketing Science, v. 13, n. 1, p. 1$13,2010$.

KELLER, K. L.; LEHMANN, D. R. Brands and branding: research findings and future priorities. Marketing Science, v. 25, n. 6, p.740-759, 2006.

MITCHELL, A. The laws of brand gravity. International Commerce Review, v. 10, n. 1, p. 76-81, 2011.

NADAR, E. N.; VIJAYAN, S. Managerial economics. New Delhi: Phi Learning, 2012.

OLIVEIRA-CASTRO, J. M.; JAMES, V. K.; FOXALL, G. R. Post reinforcement pause in grocery shopping: comparing interpurchase times across products and consumers.

Psychological Record, v. 57, n. 4, p. 483-500, 2007.

OLIVEIRA-CASTRO, J. M. et al. Consumer-based brand equity and brand performance. The Service Industries Journal, v. 28, n. 4, p. 445-461, 2008.

PENROSE, E. The theory of the growth of the firm. New York: Oxford University Press, 1959.

PORTO, R. B.; OLIVEIRA-CASTRO, J. M.; SECO-FERREIRA, D. C. What consumers say and do: planned and actual amounts bought in relation to brand benefits. The Service Industries Journal, v. 31, n. 15, p. 2559-2570, 2011.

RAMANATHAN, U.; MUYLDERMANS, L. Identifying the underlying structure of demand during promotions: a structural equation modeling approach. Expert Systems with Applications, v. 38, n. 5, p. 5544-5552, 2011.

SHARP, B. How brands grow: what marketers don't know. Victoria, Australia: Oxford University Press, 2011.

STOCK, J.; WATSON, M. Econometria. São Paulo: Addison Wesley, 2004.

WELLS, V. K.; FOXALL, G. R. Matching, demand, maximization and consumer choice. Psychological Record, v. 63, n. 2, p. 239-258 , 2013.

VAN HEERDE, H. J.; NELSIN, S. A. Sales promotion models. In: WIERENGA, B. (Ed.). Handbook of marketing decision models. New York: Springer Science, 2008. p. 17-162. 